\title{
Job Satisfaction of the Employees of the General Insurance Companies in Bangladesh
}

\author{
Mohammad Jashim Uddin ${ }^{1}$, Md. Masud Chowdhury², Masuma Yasmin ${ }^{3}$, \\ Aklima Akter ${ }^{*}$
}

${ }^{1}$ Lecturer, Department of Finance and Banking, Comilla University, Comilla-3506, BANGLADESH

${ }^{2}$ Assistant Professor, Department of Finance and Banking, Jatiya Kabi Kazi Nazrul Islam University, Trishal, Mymensingh-2220, BANGLADESH

${ }^{3}$ Lecturer, School of Business, Central Woman's University, Mission Road, Dhaka-1203, BANGLADESH

${ }^{4}$ MBA Student, Department of Accounting \& Information Systems, Comilla University, Comilla-3506, BANGLADESH

*Corresponding Contact:

Email: aklima3rd@yahoo.com

Cell Phone: +8801812090280

\begin{abstract}
This study investigates the employees' job satisfaction of general insurance companies in Bangladesh. A questionnaire was utilized to collect primary data from both public and private general insurance companies. The first part of the questionnaire comprises of the demographic profile of the respondents and the last part indicates the key measuring variables on a Likert scale ranging from 5 (strongly agree) to 1 (strongly disagree) of job satisfaction. The total number of respondents for this study was 385.74 .80 percent of the total respondents have taken from the private general insurance companies, and the remaining percentage from the public general insurance company. 70 percent of the total respondents were male respondents, and 30 percent of the total respondents were female respondents. Factor analysis and correlation matrix have been conducted to analyze the collected data. This study postulates that employees of general insurance companies have positive as well as negative feelings. Three factors reflect positive feelings toward their jobs. These factors are pay and promotional potential, the well-organized chain of command and general working condition. On the other hand, two factors are responsible for negative feelings. These factors are poor team spirit and poor job security. This paper also advocates some recommendations to maximize the positive feelings and to minimize the negative. The proper higher authority should ensure participating decision method to take any decision, the fair delegation, and direct relationship with sub-ordinates to enhance the team spirit for minimizing the dissatisfaction of the employees and should ensure the job security of the employees to get their best effort to achieve the organizational goal.
\end{abstract}

Key Words: Job Satisfaction, Public sector, Private sector, Employees, Influencing factor, General Insurance Companies 


\section{INTRODUCTION}

Today's work environment is undergoing a major shift; factors such as globalization, growing economies, and improved technology are presenting new challenges and creating new opportunities for people (Shrivastava \& Purang, 2009). The success factor for businesses is no longer cash, but human capital. Knowledge is the key to the success of a business operation. The performance of service personnel significantly affects customer satisfaction (Dunlap, Dotson, \& Chambers, 1988; Parasuraman, Zeithaml, \& Berry, 1988) and business performance (Suter, 1995). Our job is not only a source of income but also an important part of our life that contributes to our social standing (Sharma \& Jyoti, 2009). Dissatisfaction amongst human resources is undesirable and dangerous in any profession. Satisfied and committed human resources are the most significant assets of any organization, the efficient management of human resources and the maintenance of higher job satisfaction levels affect the growth and performance of an entire economy (Shrivastava \& Purang, 2009).

Job Satisfaction is an important concern in the world of professional commitments as, so far it has undoubtedly believed, the outcome of the companies, to a large extent, depends on the employees' job satisfaction. When an employee finds his or her job rewarding and reliable- this state of the employee is that he or she is satisfied to that job. Thus, job satisfaction comprises of many factors. As a result, a lot of factors function to bring about job satisfaction and at the same time lack of them is responsible for job dissatisfaction. One seems very essential concerning about the company's constant growth is employee's job satisfaction.

In the first world, this issue has been understood reasonably because they do understand that the job satisfaction of the employees is much more important than other components of the organization. In this respect, Bangladesh has yet to do something credible as the concept is relatively new in Bangladesh. But we intend to reach the global market; we ought to race with the global players. So, it has been realized the fact that job satisfaction has to be taken care of pragmatically.

Under present market forces and strict competition, the insurance companies are forced to be competitive. Contemporary companies must seek ways to become more efficient, productive, flexible and innovative, under constant pressure to improve results. What makes a firm best is not just technology, bright ideas, masterly strategy or the use of tools, but also the fact that the best firms are better organized to meet the needs of their people, to attract better people who are more motivated to do a superior job (Waterman, 1994). In this manner, the management of human resources becomes very crucial. Thus, this study on employees' job satisfaction of insurance companies was taken up. The insurance sector is of particular interest from the market orientation viewpoint, as it works with intangible commodities in which service, quality, and customer orientation are crucial elements (Lado, Maydeu-Olivares, \& Rivera, 1998).

A few partial researches have been done on prospects and problems of the general insurance companies operating in Bangladesh but the employees' job satisfaction of general insurance companies is not studied as a whole. But the company's prospects and problems largely depend on the employees' job satisfaction. 


\section{LITERATURE REVIEW}

Job satisfaction has been defined in several different ways and a definitive designation for the term is unlikely to materialize. A simple or general way to define it therefore is as an attitudinal variable: Job satisfaction is simply how people feel about their jobs and different aspects of their jobs. It is the extent to which people like (satisfaction) or dislike (dissatisfaction) their jobs (Spector, 1997). Other theorists (Rose, 2001) have viewed job satisfaction as a bi-dimensional concept consisting of intrinsic and extrinsic satisfaction dimensions. Intrinsic sources of satisfaction depend on the individual characteristics of the person, such as the ability to use initiative, relations with supervisors, or the work that the person actually performs; these are symbolic or qualitative facets of the job. Extrinsic sources of satisfaction are situational and depend on the environment, such as pay, promotion, or job security; these are financial and other material rewards or advantages of a job. Both extrinsic and intrinsic job facts should be represented, as equally as possible, in a composite measure of overall job satisfaction. Job satisfaction, which has been studied extensively, is a function of several important variables especially the characteristics of the job itself (Hackman and Oldham, 1975), and the organizational climate (Litwin and Stringer, 1968). Job characteristics have been shown in many studies to influence the job satisfaction of employees (see for instance, the extensive review by Rabinowitz and Hall, 1977). Various organizational climate factors such as communication, participation in decision-making, and stress have also been examined as to their relationship to job satisfaction and found to be significant predictors. While two-way communication (Bateman, 1977; Price, 1972) and participation in making job-related decisions (Patchen, 1970; White and Ruh, 1973) have a positive effect on job satisfaction, stress has a negative relationship, in the sense that the greater the amount of stress experienced by employees, the lesser is the extent of job satisfaction experienced by them (Bhagat, 1982; Lyons, 1971). Organizations have significant effects on the people who work for them and some of those effects are reflected in how people feel about their work (Spector, 1997). This makes job satisfaction an issue of substantial importance for both employers and employees. As many studies suggest, employers benefit from satisfied employees as they are more likely to profit from lower staff turnover and higher productivity if their employees experience a high level of job satisfaction. However, employees should also 'be happy in their work, given the amount of time they have to devote to it throughout their working lives' (Nguyen, Taylor and Bradley, 2003a). The following passage summarizes the importance of job satisfaction for both employers and their workers: Job satisfaction is important in its own right as a part of social welfare, and this (simple) taxonomy [of a good job] allows a start to be made on such questions as 'In what respects are older workers' jobs better than those of younger workers?' (And vice versa), 'Who has the good jobs?' and 'Are good jobs being replaced by bad jobs?' In addition, measures of job quality seem to be useful predictors of future labor market behavior. Workers' decisions about whether to work or not, what kind of job to accept or stay in, and how hard to work are all likely to depend in part upon the worker's subjective evaluation of their work, in other words on their job satisfaction. (Clark, 1998). Ahmed and Das (2014) conveyed that the employees of the commercial bank have positive as well as negative feelings of their job. The paper also advocated some recommendations to maximize positive attitude and minimize negative attitude of the commercial bank employees in Bangladesh. Haque (2012) revealed that the overall job satisfaction of commercial bank officials is at the positive level i.e. more than fifty percent of the bank officials are satisfied with their job. Job satisfaction of the bank officials in Bangladesh is significantly dependent upon general working conditions, pay and promotional potentials, and work relationships. Kabir, M.M., (2011) showed that job satisfaction depends on the Salary and benefits, the nature of the job, the environment, working conditions, leadership, job design, job 
enrichment, job rotation, job enlargement, the style of management as well as the culture, empowerment, employee involvement and work groups. Job satisfaction is no simple phenomenon. It is a complex deal with multiple facets. Many things influence it, such as salary, the working environment, communication, autonomy and organizational commitment (Lane, K.A., et al., 2010). Noor, M.S. (2009) showed that there exists a good and positive relationship between fairness of work policies, insurance policies and working hours and job satisfaction. Brown, G., et al. (2008) showed that job satisfaction depends upon work condition which is being defined by the employee's work place, the work itself, the instruments used in that work, the rules of the organization and their policies. Willem, E.T.(2007) postulates that the magnitude of job satisfaction largely depends on lower convenience costs and social, organizational and personal reward. Job satisfaction is considered a strong predictor of overall individual well-being (Diaz-Serrano and Cabral Vieira, 2005), as well as a good predictor of intentions or decisions of employees to leave a job (Gazioglu and Tansel, 2002).

\section{OBJECTIVE OF THE STUdY}

The objective of the study is to identify the employees' job satisfaction in the general insurance companies in Bangladesh.

\section{Research Methodology}

Research methodology includes Research design, Data source and collection procedures; sampling method, sample unit, sample size and data analysis.

\section{Research Design}

It is an exploratory research to identify the variable that effect the employee's job satisfaction of general Insurance companies. To identify the variables of job satisfaction, factor analysis has been done and based on outcomes of the factor analysis, the findings and analysis part has been done. The study involved a questionnaire survey, conducted on the employees of nine (09) private and one (01) nationalized general insurance company. The information gathered from the employees at their respective workplace.

\section{Data Source and Data collection Procedures}

For smooth and accurate study everyone has to follow some rules \& regulations. The study inputs were collected from two sources:

Primary sources:

A questionnaire was used to acquire primary data from the employees of various general insurance Companies. The questionnaire consists of two parts. The first part of the questionnaire started with general information of the respondents and the last part of questionnaire is comprised of the key measuring variables on a Likert scale ranging from 5 (strongly agree) to 1 (strongly disagree) of job satisfaction.

Secondary Sources:

- Annual reports of the respective general insurance companies

- Report of Bangladesh Insurance Academy

- Report of Insurance Development and Regulatory Authority

- Insurance Journals

- Extensive literature searches by these documents of publication

- Website of the respective general insurance companies 


\section{Sampling Method}

Here the non-probability convenience sampling method was used to gather data as of the sample of this research. The convenience sample for this study is measured by the employees of respective general insurance companies who are working within the respective organizations.

\section{Sample Units}

Among the one (01) public and forty-five (45) private general insurance companies, this study is conducted on one (01) public and nine (09) private general insurance companies. The list of the general insurance companies is below:

1. Sadharan Bima Corporation (Gen. Ins)

2. Agrani Insurance Company Ltd.

3. Bangladesh National Insurance Company Ltd

4. Global Insurance Ltd

5. Green Delta Insurance Company Ltd
6. Janata Insurance Company Ltd.

7. Karnaphuli Insurance Company Ltd.

8. Meghna Insurance Company Ltd.

9. Phonix Insurance Company Ltd.

10. Provati Insurance Company Ltd.

\section{Sample Size Determination}

The sample size has been determined considering the following assumption:

A total number of employees was selected randomly from the public and privet sector of the general insurance companies. The sample percentage is normally distributed. Since the distribution is normal, so probability of success and failure are equal, i.e., $\mathrm{p}=\mathrm{q}=0.5$

Here, given study population size $\mathrm{N}=8634$ (Total number of employees of the selected public (01) and private (09) sector general insurance companies) [source: Respective Insurance companies and Bangladesh Bureau of Statistics, 2007-2008]

The desired sample size ' $\mathrm{n}$ ' would be $\mathrm{n}=\frac{p q \mathrm{z}^{2}}{D^{2}}$

Where, $\mathrm{n}=$ Size of sample;

$\mathrm{p}=$ estimated proportion of successes, here it is $50 \%$ i.e., 0.5 ;

$\mathrm{q}=1-\mathrm{p}$, or estimated proportion of failures, i.e., $1-0.5=0.5$;

$\mathrm{z}=$ standard normal deviate, usually set at 1.96 corresponds to $95 \%$ confidence limit;

$\mathrm{D}=$ levels of precision, here it is 0.05

This the sample size of $\mathrm{n}=385$

Distribution of Sample Size in Different Sector under Proportional Allocation Method:

\begin{tabular}{|c|c|c|c|c|c|}
\hline \multicolumn{6}{|c|}{ Table: Distribution of the Sample: } \\
\hline & & & \multicolumn{2}{|c|}{$\begin{array}{l}\text { Ownership of } \\
\text { the company }\end{array}$} & \multirow[t]{2}{*}{ Total } \\
\hline & & & Private & public & \\
\hline \multirow{4}{*}{$\begin{array}{l}\text { Gender of the } \\
\text { responders }\end{array}$} & Male & $\%$ within Gender of the respondent & $69.3 \%$ & $30.7 \%$ & $100.0 \%$ \\
\hline & $70 \%$ & $\%$ within Ownership of the company & $64.9 \%$ & $85.3 \%$ & $70.0 \%$ \\
\hline & Female & $\%$ within Gender of the respondent & $87.7 \%$ & $12.3 \%$ & $100.0 \%$ \\
\hline & $30 \%$ & $\%$ within Ownership of the company & $35.1 \%$ & $14.7 \%$ & $30.0 \%$ \\
\hline \multirow{2}{*}{\multicolumn{2}{|c|}{ Total }} & $\%$ within Gender of the respondent & $74.8 \%$ & $25.2 \%$ & $100.0 \%$ \\
\hline & & $\%$ within Ownership of the company & $100.0 \%$ & $100.0 \%$ & $100.0 \%$ \\
\hline
\end{tabular}


The total number of respondents is 385. By doing the cross tabulation of the study, it is seen that 74.80 percent of the total respondents are taken from the private general insurance companies and 25.20 percent of the total respondents are taken from the public general insurance company. Among all the respondents 70 percent are male respondents and 30 percent are female respondents. The study also represents that among all the male respondents 69.30 percent are taken from the private general insurance companies and 30.70 percent are taken from the public general insurance company. On the other hand, among all the female respondents 87.70 percent are taken from the private general insurance companies and 12.30 percent are taken from the public general insurance company. From the view point of ownership of the insurance companies, 64.90 percent male and 35.10 percent female are taken from the private general insurance companies and 85.30 percent male and 14.70 percent female are taken from the public general insurance company.

\section{Data Analyzing Procedures}

The variables are used to in the survey instrument have been abbreviated to facilitate the analysis procedures (appendix-1). Statistical tools were used to analyze the survey data. Factor analysis has been used to expose the factors of job satisfaction.

\section{RESULTS AND Discussions}

\section{Survey Results}

The total number of respondents for this study was 385. These 385 respondents gave their responses on the following variables:

\begin{tabular}{|l|c|c|c|c|c|}
\hline & $\begin{array}{c}\text { Strongly } \\
\text { Disagree(1) }\end{array}$ & $\begin{array}{c}\text { Disagree } \\
(2)\end{array}$ & $\begin{array}{c}\text { Neutral } \\
(3)\end{array}$ & $\begin{array}{c}\text { Agree } \\
(4)\end{array}$ & $\begin{array}{c}\text { Strongly } \\
\text { Agree (5) }\end{array}$ \\
\hline Working hour for each week (V1) & $2.59 \%$ & $10.00 \%$ & $20.00 \%$ & $44.44 \%$ & $22.96 \%$ \\
\hline Feeling of personal accomplishment (V2) & 4.81 & 13.33 & 18.52 & 43.70 & 19.63 \\
\hline Flexibility in scheduling (V3) & 4.81 & 13.33 & 20.37 & 42.96 & 18.52 \\
\hline Clearly define quality goal (V4) & 3.33 & 9.26 & 19.63 & 45.19 & 22.59 \\
\hline $\begin{array}{l}\text { Proper authority to utilize skills, abilities, } \\
\text { and resources (V5) }\end{array}$ & 2.59 & 10.37 & 16.67 & 45.56 & 24.81 \\
\hline Clearly defined chain of command (V6) & 5.56 & 17.04 & 18.52 & 38.52 & 20.37 \\
\hline Liability of the authority (V7) & 2.59 & 10.00 & 17.78 & 44.07 & 25.56 \\
\hline Location of work (V8) & 4.81 & 14.07 & 16.67 & 40.37 & 24.07 \\
\hline Supervisors encourage to being best (V9) & 2.59 & 11.85 & 18.15 & 41.48 & 25.93 \\
\hline Amount of benefit in vacation (V10) & 4.07 & 11.48 & 17.04 & 44.44 & 22.96 \\
\hline Salary (V11) & 4.81 & 12.22 & 19.63 & 44.07 & 19.26 \\
\hline Opportunity of promotion (V12) & 3.33 & 10.37 & 20.37 & 43.70 & 22.22 \\
\hline Other benefits from job (V13) & 5.19 & 11.85 & 18.89 & 44.44 & 19.63 \\
\hline Direct relationship with subordinates (V14) & 3.70 & 8.15 & 18.52 & 47.78 & 21.85 \\
\hline Residence and transport facility (V15) & 4.81 & 11.85 & 22.96 & 42.96 & 17.41 \\
\hline Recognition of accomplishing work (V16) & 2.96 & 9.26 & 16.67 & 46.30 & 24.81 \\
\hline $\begin{array}{l}\text { Opportunity for periodic changes in } \\
\text { duties (V17) }\end{array}$ & 5.93 & 14.07 & 16.67 & 42.96 & 20.37 \\
\hline Opportunity to learn new skill (V18) & 2.59 & 8.52 & 17.41 & 45.93 & 25.56 \\
\hline $\begin{array}{l}\text { Opportunity to utilize skills and } \\
\text { talents (V19) }\end{array}$ & 5.19 & 13.33 & 17.78 & 42.96 & 20.74 \\
\hline $\begin{array}{l}\text { Support for additional training } \\
\text { and education (V20) }\end{array}$ & 2.59 & 9.26 & 18.89 & 45.56 & 23.70 \\
\hline $\begin{array}{l}\text { Loss the job at the desire of the } \\
\text { higher authority (V21) }\end{array}$ & 4.81 & 12.22 & 18.52 & 44.07 & 20.37 \\
\hline Source Fly & & & & & \\
\hline
\end{tabular}

Source: Filled up questionnaires 


\section{Factor Analysis Result}

Kaiser-Meyer Olkin measure of sampling adequacy (KMO):

\begin{tabular}{|l|l|l|}
\hline \multicolumn{3}{|l|}{ KMO and Bartlett's Test } \\
\hline Kaiser-Meyer-Olkin Measure of Sampling Adequacy. & .819 \\
\hline \multirow{3}{*}{ Bartlett's Test of Sphericity } & Approx. Chi-Square & 3645.790 \\
\cline { 2 - 3 } & Df & 210 \\
\cline { 2 - 3 } & Sig. & .000 \\
\hline
\end{tabular}

The Kaiser-Meyer-Olkin (KMO) measure of sampling adequacy is an index used to examine the appropriateness of factor analysis. A high value (between 0.5 and 1.0) indicates that factor analysis is appropriate. Value bellow 0.5 implies that factor analysis may not be appropriate. (Malhotra, 2008). To measuring the appropriateness of the factor analysis, Kaiser-Meyer-Olkin (KMO) measure of sampling adequacy has been examined. The value of $\mathrm{KMO}$ is 0.819 , which is an indication of sampling adequacy and thus the appropriateness of the factor analysis. The Bartlett's Test of Sphericity tests the adequacy of the correlation matrix that yields a value of 210, and an associated level of significance is smaller than 0.01. Thus, the hypothesis that the correlation matrix is an identity matrix that can be rejected, i.e. the correlation matrix has significant correlations among at least some of the variables.

\section{Correlation Matrix Analysis}

The variables must be correlated for the factor analysis to be appropriate. If the selected variables have poor correlation between them, the resulting factors may not mean anything significant other than the reproduction of the original variables. From the correlation matrix (using SPSS), it is found that significant correlation exists between several variables. The variable V18 is highly correlated (.742) with variable V20. Beside this, variables V20 and V18, V19 and V18, V16 and V18, V11 and V13, V4 and V2, V15 and V13, V5 and V4, V12 and $\mathrm{V} 11$ is also highly correlated with each other and the level of correlation between this variables are $.742, .728, .705, .686, .682, .644, .629$ and .627 respectively. In the same way, there exists a significant correlation between variables V7 and V9 (.599), V6 and V9 (.598), V8 and V10 (.592), V1 and V5 (.554), V14 and V12 (.540), V3 and V1 (.534), V17 and V18 (0.446), V21 and V14 (.348) etc.

\section{Anti-image correlation matrix}

Anti-image correlation matrix is used to measure the sampling adequacy level and it implies that variables that have anti-image correlation below the acceptable level (0.5) which can be excluded from the factor analysis. The Anti-image correlation matrix (using SPSS) shows that all the variables used in the study have anti-image correlation coefficients above the acceptable value (0.5). Since all the variables have anti-image correlation coefficient above the acceptable value, all the variables should be included in the factor analysis.

\section{Determination of the number of factors}

In this approach, only factors with eigen values greater than 1.0 are retained; the other factors are not included in the model. An eigen value represents the amount of variance associated with the factor. Hence, only factors with a variance greater than 1.0 are included. Factors with variance less than 1.0 are no better than a single variable, because due to standardization, each variable has a variance of 1.0. (Malhotra, 2008). The Total Variance Explained (found by using SPSS) presents the number of common factors extracted, the eigen values associated with these factors, the percentage of total variance accounted for by 
each factor, and the cumulative percentage of total variance accounted for the factors. Using the criterion of retaining only factors with eigen values of 1 or greater, five factors were retained for rotation. These five factors accounted for $34.283 \%, 17.429 \%, 7.394 \%, 6.634 \%$ and $4.770 \%$ of the total variance respectively, for a total of $70.510 \%$.

\section{Rotated Component Matrix}

The research could be more logical if the researcher use rotated component matrix. The rotated component matrix avoids the limitation of the component matrix of including the variable under a specified factor. In the rotated factor matrix (Appendix-02), factor 1 indicates some motivational factors related to financial and non-financial incentives and it contains nine variables. Each of the variables is responsible for positive feelings among the employees towards their job (e.g. V11 = I am satisfied with my salary; V12 = I am satisfied with the opportunity of promotion; V13 = I am satisfied with the benefits that offer my job (Health insurance, life insurance, etc.); V15 = I am satisfied with residence and transport facility; V16 = I am satisfied with that the job recognizes the accomplished work; V17 = I am satisfied with the adequate opportunity for periodic changes in duties; V18 = I am satisfied with the opportunity to learn new skill; V19 = I am satisfied with the opportunity to utilize skills and talents; V20 = I am satisfied with the support for additional training and education). Therefore, this factor may be labeled as Pay and promotional potential. Factor 2 includes five variables and those help the employee to complete the work in due time with due responsibilities (e.g. V2 = I am satisfied with the feeling of personal accomplishment; V4 $=\mathrm{I}$ always receive clearly define quality goal from the higher authority to accomplish my work in due time; V5 = I have proper authority to utilize my skills, abilities and resources; V6 = clearly defined chain of command helps me to receive my information from management timely; V9 = I found that the supervisors encourage to being best in my career). Therefore, this factor may be labeled as Well organized chain of command. Factor 3 contains four variables that reflect enthusiasm about their job (e.g. V1 = I am satisfied with the working hour for each week; V3 = I found flexibility in scheduling; V8 = I am satisfied with the location of work; V10 = I am satisfied with the amount which is paid in vacation time. Therefore, this factor may be labeled as General working conditions. Factor 4 contains two variables that raise a risk of depression among the employees. This factors also create job dissatisfaction among the employees (e.g. V7 = I always liable to my senior authority as well as junior authority always liable to me; V14 = I found that I can hardly maintain the direct relationship with all of my subordinates). Therefore, this factor may be labeled as poor team spirit. Factor 5 contains only one item and it clearly possess stress on the employees since they know that they can loss their job any time (e.g. V21 = I can loss my job at the desire of the higher authority when they want.). Therefore, this factor may be labeled as Poor job security.

The following table is a part of the outcome of factor analysis-"Rotated Component Matrix".

\begin{tabular}{|l|l|c|c|c|}
\hline Factor & Name of the Factor & \multicolumn{3}{|c|}{ Rotation Sums of Squared Loadings } \\
\cline { 3 - 5 } & & $\begin{array}{c}\text { Eigen } \\
\text { Value }\end{array}$ & $\begin{array}{c}\% \text { of } \\
\text { Variance }\end{array}$ & $\begin{array}{c}\text { Cumulative } \\
\%\end{array}$ \\
\hline 1 & Pay and promotional potential & 5.402 & 25.724 & 25.724 \\
\hline 2 & Well organized chain of command & 3.686 & 17.554 & 43.278 \\
\hline 3 & General working conditions & 2.455 & 11.689 & 54.967 \\
\hline 4 & Poor team spirit & 1.665 & 7.928 & 62.895 \\
\hline 5 & Poor job security & 1.599 & 7.615 & 70.510 \\
\hline
\end{tabular}

Extraction Method: Principal Component Analysis 
The table shows that the eigen value of pay and promotional potential Factor is 5.402 which imply that the variance explained by the first factor is 25.724 percent. The eigen value of the well-organized chain of command factor is 3.686 which imply that the variance explained by the second factor is 17.554 percent. General working conditions factor explains 11.689 percent of variances. The Poor team spirit factor explains 7.928 percent and Poor job security factor explains 7.615 percent of variances. The result of the factor analysis shows that these five factors collectively produce at about 70.510 percent variance in the data set.

This study reveals five factors of job satisfaction or dissatisfaction. These factors can be categorized into two categories. These are positive feelings and negative feelings. Three factors reflect positive feelings toward their jobs. These factors are pay and promotional potential, wellorganized chain of command and general working condition. On the other hand, two factors are responsible for negative feelings. These factors are poor team spirit and poor job security.

\section{RECOMmEndATIONS AND CONCLUSION}

The results suggest that the concerned authority should take proper steps to maximize the positive feelings as well as to minimize the negative feelings of the employees. Pay and promotional incentives should be increased for the employees of the general insurance companies which should be sufficient enough to live a standard life, and the authority should also ensure the promotion of each employee when it became due. The policy makers and managers should ensure the clearly defined goals and chain of command that helps the employees to accomplish their work in due time by using their skills, abilities, and resources. The employees should give the proper authority, information and encourage for accomplishing their task and a feeling of personal accomplishment. The authority should ensure the fairness in every sphere of the organization. Poor team spirit is the burning issue of job dissatisfaction. Team spirit largely depends on the relationship of the employees within and outside the organization. Most of the employees conveyed that in most cases, the higher authority remains reluctant to hear their problems and always force them to do a job regardless of their suggestions. They also conveyed that the higher authority does not ensure the fair delegation of authority and direct relationship with the sub-ordinates. So, the proper higher authority should ensure participating decision method to take any decision, the fair delegation of authority, and direct relationship with sub-ordinates to enhance the team spirit for minimizing the dissatisfaction of the employees. In the general insurance company, job security is an important aspect of job satisfaction. If an employee always feels fear to lose his or her job than it is not possible for him/her to give his or her best effort to achieve a goal. Thus, the concerned authority should ensure the job security of the employees to get their best effort to achieve the organizational goal.

\section{REFERENCES}

Ahmed K. F and Das P.C. (2013), Job satisfaction of the employees of commercial bank of Bangladesh, ICMEA, Voll-XLII, No. 2, March-April 2014, pp. 31-39.

Brown, G., et al., (2008), The impact of supervisory adaptive selling and supervisory feedback on salesperson performance," Index Marketing Management, pp: 447-454.

Chen, S.H., Yang, C.C., Shiau, J.Y., and Wang, H.H. (2006), "the development of an employee satisfaction model for higher education", The TQM Magazine, Vol. 18, No. 5, pp. 484-500.

Cherrington D.J. (1994), Organizational Behavior (2nd ed.)[M]. Boston: Allyn and Bacon, Inc.

Cranny, C.J., Smith, P.C., and Stone, E.F. (1992), Job satisfaction: How people feel about their jobs and how it affects their performance, Lexington Books, New York.

Dunlap, B.J., Dotson, M.J., \& Chambers, T.M. (1988), Perceptions of real-estate brokers and buyers: A sales-orientation, customer-orientation approach. Journal of Business Research, 17(2), 175-187. 
Greasley, K., Bryman, A., Dainty, A., Price, A., Soetanto, R., and King, N. (2005), “Employee perceptions of empowerment", Employee Relations, Vol. 27, No. 4, pp. 354-368.

Hadebe, T.P. (2001), "Relationship between motivation and job satisfaction of employees at Vista Information Services", M.A. dissertation, Rand Afrikaans University, Johannesburg

Hagihara, A., Babazono, A., Nobutomo, K., and Morimoto, K. (1998), Work versus non-work predictors of job satisfaction among Japanese white-collar workers", Journal of Occupational Health, Vol. 40, pp. 285-292.

Haque, M. M., (2012), Job satisfaction of the employees of the commercial banks: Bangladesh perspective, Bank Parikrama. XXXVII-IV \& V, 87-98

Herzberg, F., Mausner, B., \& Synderman B. B. (1959), The Motivation to Work, Wiley \& Sons Inc.: New York.

Hulin, C. L., \& Smith, P. C. (1964), "Sex differences in job satisfaction", Journal of Applied Psychology, $48(2), 88-92$.

Judge, T.A. \& Watanabe, S. (1993), "Another look at the job satisfaction - life satisfaction relationship", Journal of Applied Psychology, 78, 939 - 948

Judge, T.A., Hulin, C.L. (1993), "Job satisfaction as a reflection of a disposition: a multiple sources causal analysis", Organizational Behaviour and Human Decisions Processes, Vol. 56, pp. 388-421.

Kabir, M.M., (2011), Factors Affecting Employee Job Satisfaction of Pharmaceutical Sector., Australian Journal of Business and Management Research, 11(4).

Lado, L., Maydeu-Olivares, A., \& Rivera, J. (1998), Measuring market orientation in several populations: A structural equations and model. European Journal of Marketing, 32(1/2), 23-39.

Lane, K.A., et al., (2010), A study of nurse faculty job satisfaction in community colleges in Florida., European Journal of Management and Research, pp: 16-26.

Locke, E.A., (1969), "What is job satisfaction", Organizational Behavior and Human Performance, Vol. 4, Iss. 4, pp. 309-336.

Lyons, T. F. (1971), "Role clarity, need for clarity, satisfaction, tension and withdrawal”, Organizational Behavior and Human Performance, 6, 99-110.

McCue CP and Gianakis GA (1997) "The Relationship between Job Satisfaction and Performance: The Case of Local Government Finance Officers in Ohio", Public Productivity \& Management Review 21(2): 170-191.

Megginson, L.C., Mosley, D.C. \& Pietri, P.H. (1982), “Management concepts and applications” (4th ed.) New York: Harper Collins.

Newstorm John W. and Keith Davis, (2000), Organisational Behavior at work .Tenth Edition, Tata Mc GrawHill, New Delhi, Pp. 265-266.

Noor, M.S., (2009), Determinants of Employee Retention in Telecom Sector of Pakistan, CBRC, pp: 18.

Okpara, (2004), "Job Satisfaction and Organizational Commitment: Are there differences between American and Nigerian Managers Employed in the US MNCs in Nigeria?", Academy of Business \& Administrative Sciences, Briarcliffe College, Switzerland.

Parasuraman, A., Zeithaml, V.A., \& Berry, L.L. (1988), SERVQUAL: A multiple-item scale for measuring customer perceptions of service quality. Journal of Retailing, 64(1), 12-40.

Rousseau, D. (1978), “Characteristics of departments, positions, and individuals: contexts for attitudes and behaviors", Administrative Science Quarterly, Vol. 23, pp. 521-540.

Sempane, M.E., Rieger, H.S. \& Roodt, G. (2002), "Job satisfaction in relation to organizational culture", South African Journal of Industrial Psychology, 28(2), 23 -30.

Sharma RD, Jyoti J (2009), Job satisfaction of university teachers: an empirical study. J. Serv. Res., 9(2): 51-80.

Shrivastava, A., \& Purang, P. (2009), Employee satisfaction of job satisfaction: Comparative study on Indian banks. Asian Academy of Management Journal, Vol. 14, No. 2, 65-78.

Spector, P. E. (1997) Job satisfaction: Application, assessment, cause and consequences Thousand Oaks, CA: Sage New York: John Wiley \& Sons, Inc.

Spector, P.E. (2003), Industrial and organizational psychology - Research and practice (3rd ed.).

Suter, T.A. (1995, The integration of internal marketing into the organizational culture of service firms (pp. 431-435). Little Rock, Arkansas: Southern Marketing Association.

Waterman, R. H. (1994), What America does right: Learning from companies that put people first. New York: Norton. 


\section{APPENDICES}

\section{Appendix 1}

\begin{tabular}{|l|c|}
\hline Questions & Variables \\
\hline Working hour for each week & V1 \\
\hline Feeling of personal accomplishment & V2 \\
\hline Flexibility in scheduling & V3 \\
\hline Clearly define quality goal & V4 \\
\hline Proper authority to utilize my skills, abilities and resources & V5 \\
\hline Clearly defined chain of command & V6 \\
\hline Liability of the authority & V7 \\
\hline Location of work & V8 \\
\hline Supervisors encourages to being best & V9 \\
\hline Fair amount of benefit in vacation & V10 \\
\hline Salary & V11 \\
\hline Opportunity of promotion & V12 \\
\hline Other benefits from job & V13 \\
\hline Direct relationship with subordinates & V14 \\
\hline Job security & V15 \\
\hline Recognition of accomplish work & V16 \\
\hline Opportunity for periodic changes in duties & V17 \\
\hline Opportunity to learn new skill & V18 \\
\hline Opportunity to utilize skills and talents & V19 \\
\hline Support for additional training and education & V20 \\
\hline Loss the job at the desire of the higher authority & V21 \\
\hline
\end{tabular}

\section{Appendix 2}

\begin{tabular}{|l|c|c|c|c|c|}
\hline \multirow{2}{*}{ Rotated Component Matrixa } & \multicolumn{5}{|c|}{ Component } \\
\cline { 2 - 6 } & 1 & 2 & 3 & 4 & 5 \\
\hline New and Better Ways of Doing Things & .171 & .499 & .552 & -.073 & .091 \\
\hline Feeling of Personal Accomplishment. & .123 & .852 & .169 & -.060 & -.044 \\
\hline Have the Tools and Resources & .219 & .313 & .702 & -.231 & -.202 \\
\hline Clearly Defined Quality Goals & .137 & .797 & .242 & -.074 & .067 \\
\hline Use of Skills and Abilities & .076 & .734 & .320 & .119 & .234 \\
\hline Information Receive from Management & .139 & .531 & .216 & .225 & -.523 \\
\hline Involvement in Decisions that Affect Work & -.056 & .478 & .329 & .606 & .073 \\
\hline Management Looks for Suggestions and Leadership & .039 & .413 & .634 & .303 & -.073 \\
\hline Supervisor Encourages Being Best & .108 & .730 & .090 & .431 & -.169 \\
\hline Valued by Supervisor & .101 & .199 & .805 & .164 & .074 \\
\hline Positive Image to Friends and Family & .718 & .088 & .337 & .240 & -.254 \\
\hline How Job Performance Evaluated & .599 & .221 & .191 & .394 & .241 \\
\hline Training Provided for Current Job & .814 & -.051 & .183 & .215 & -.254 \\
\hline Team Spirit and Cooperation & .570 & -.053 & .016 & .604 & .308 \\
\hline Benefits Package & .789 & .001 & .147 & .081 & -.019 \\
\hline Continued employment & .789 & .213 & -.080 & .020 & .215 \\
\hline Career Aspirations Can be achieved & .507 & .074 & .202 & -.420 & .110 \\
\hline Management is Supportive of Its Employee & .837 & .142 & .045 & -.142 & .249 \\
\hline Like the work I do & .700 & .170 & -.002 & -.038 & .500 \\
\hline The communication Is Timely and Accurate & .819 & .140 & .027 & -.130 & -.063 \\
\hline How Satisfied with the Job & .125 & .051 & .022 & .125 & .717 \\
\hline Extraction Method: Principal Component Analysis. & & & & & \\
Rotation Method: Varimax with Kaiser Normalization. & & & & & \\
\hline a. Rotation converged in 8 iterations. & & & & & \\
\hline
\end{tabular}




\section{Appendix 3}

\section{QUESTIONNAIRE}

Dear Respondent,

For my research purpose, I need to collect data regarding "Job Satisfaction of the Employees of the General Insurance Companies in Bangladesh". It will be highly appreciable if you provide me your valuable opinion regarding this issue. I also assure that this data will be used for only research purpose. The collected information from you will be reserved with strict confidentiality. Thanks to you in advance!

Name of the Respondent :

Sex

Education

: $\quad$ (a) Male (b) Female

Marital status

(a) Below S.S.C ( b) S.S.C

(e) Masters

(f) PHD

Types of firm $\quad: \quad \begin{array}{ll}\text { (a) Public } & \text { (b) Private }\end{array}$

(a) Married

(b) Unmarried

The following section represents a list of various satisfaction levels that you have achieved while you are working in your insurance company. Please indicate the degree of satisfaction by giving the tick marks in the appropriate box.

Strongly Agree 5

Agree 4

Neutral 3

Disagree 2

Strongly Disagree 1

\begin{tabular}{|c|c|c|c|c|c|c|}
\hline SL. No. & Questions & 1 & 2 & 3 & 4 & 5 \\
\hline 1 & I am satisfied with the working hour for each week & & & & & \\
\hline 2 & I am satisfied with the feeling of personal accomplishment & & & & & \\
\hline 3 & I find flexibility in scheduling & & & & & \\
\hline 4 & $\begin{array}{l}\text { I always receive clearly define quality goal from the higher authority to } \\
\text { accomplish my work in due time }\end{array}$ & & & & & \\
\hline 5 & I have proper authority to utilize my skills, abilities and resources & & & & & \\
\hline 6 & I found clearly defined chain of command & & & & & \\
\hline 7 & $\begin{array}{l}\text { I always liable to my senior authority as well as junior authority } \\
\text { always liable to me }\end{array}$ & & & & & \\
\hline 8 & I am satisfied with the location of work & & & & & \\
\hline 9 & I find that the supervisors encourages to being best in my career & & & & & \\
\hline 10 & I am satisfied with the amount which is paid in vacation time & & & & & \\
\hline 11 & I am satisfied with my salary & & & & & \\
\hline 12 & I am satisfied with the opportunity of promotion & & & & & \\
\hline 13 & $\begin{array}{l}\text { I am satisfied with the benefits that offer my job (Health insurance, } \\
\text { life insurance, etc.) }\end{array}$ & & & & & \\
\hline 14 & I find that I can hardly maintain direct relationship with all of my subordinates & & & & & \\
\hline 15 & I am satisfied with job security & & & & & \\
\hline 16 & I am satisfied with that the job recognize the accomplish work & & & & & \\
\hline 17 & I am satisfied with the adequate opportunity for periodic changes in duties & & & & & \\
\hline 18 & I am satisfied with the opportunity to learn new skill & & & & & \\
\hline 19 & I am satisfied with the opportunity to utilize skills and talents & & & & & \\
\hline 20 & I am satisfied with the support for additional training and education & & & & & \\
\hline 21 & I can loss my job at the desire of the higher authority when they want & & & & & \\
\hline
\end{tabular}

Thanks for your cordial cooperation!

--0-- 